\title{
Promoting Undergraduate Research and Education through Extracurricular EPA P3 Projects
}

\section{Prof. Woo Hyoung Lee P.E., University of Central Florida}

Dr. Woo Hyoung Lee, P.E. is an assistant professor in the Department of Civil, Environmental, and Construction Engineering at the University of Central Florida (UCF). He received his Ph.D. in environmental engineering from the University of Cincinnati in 2009. Prior to joining UCF in 2013, he worked for U.S. Environmental Protection Agency's National Risk Management Research Laboratory as a post-doc. His primary research area is to develop electrochemical microsensors for in situ investigation of physical and chemical dynamics in microenvironments (e.g., biofilm, corrosion, emulsions, or plant) by combining with nano and biotechnology. His other research interest is to develop renewable (bio)energy processes for environmental sustainability. He is currently a registered professional engineer. 


\section{Promoting Undergraduate Research and Education through Extracurricular EPA P3 Projects}

\section{Introduction and Objectives}

The importance of multi-interdisciplinary design experiences is well-highlighted in the ASCE Body of Knowledge [1] and the ABET Engineering Accreditation Commission [2]. However, there have not been many reports or documents of multidisciplinary extracurricular activities for environmental engineering students with students from other disciplines. The P3 Program is an annual-based unique national student design competition for designing solutions for a sustainable future focusing on People, Prosperity and the Planet (P3) supported by U.S. Environmental Protection Agency (EPA). The EPA's P3 program is intended to support science-based projects and designs developed by multi-interdisciplinary student teams that benefit people by improving their quality of life, promote prosperity by developing local economies, and protect the planet by conserving resources and minimizing pollution. Through this national student design competition, undergraduate and graduate students can gain new skills and knowledge as they research, develop, design, and implement scientific and technical solutions to environmental challenges. The P3 Award Program is composed of two phases (Phase I and Phase II) that award grants on a competitive basis. The $\mathrm{P} 3$ award is nationally highly competitive with selection of 20 awards for Phase I and only 3 awards for Phase II per year. This paper describes the development of multidisciplinary year-long national student design project from the concept development, students recruit and involvements, and proposal development to the execution of the awarded research projects.

\section{Methods}

Since 2015, a new and innovative advising method by integrating education and research projects for undergraduate students has been initiated, developed and successfully conducted over 4 years through extracurricular P3 program. In this paper, three $\mathrm{P} 3$ awards $\left(12^{\text {th }}, 14^{\text {th }}\right.$, and $15^{\text {th }}$ ) are introduced.

Since 2015, in the Department of Civil, Environmental and Construction Engineering at the University of Central Florida, a new and innovative undergraduate research and project development program was successfully initiated by integrating education and research projects for undergraduate students through extracurricular EPA P3 projects. For 4 years, the PI's student team received three Phase I awards and one Phase II award (award pending). In 2015, the PI's student team won a $12^{\text {th }} \mathrm{P} 3$ award with a research title of "Algae Biofuel Osmosis Dewatering (ABODE): A novel process for biofuel feedstock generation and advances in microalgae separation using forward osmosis (FO)", which is a first in the PI's university history, and exhibited a prototype of the FO process for microalgae separation at the $4^{\text {th }}$ USA Science \& Engineering Festival in Washington DC in 2016, the largest and only national science festival, featuring nationwide contests and school programs. The student team attracted the interests of hundreds of K-12 students and parents, and received an honorable mentions award in sustainable energy. The second $\mathrm{P} 3$ project was to develop a superhydrophobic sponge for oil spill events with a title of "A Novel 2D MoS 2 Sponge Oil-Water Separator (MDSOS)". The recent award was to develop a simple lead detection sensor for drinking water with a title of "A Biopolymer- 
based Simple Lead Check in Tap Water". Most P3 research projects were focused on safe and sustainable water resources based on the PI's previous research experiences.

\section{Results and discussion \\ Comparison between existing extracurricular activities and EPA P3}

Extracurricular activities have been used to fill the current gaps in the undergraduate engineering curriculum [3]. Typical extracurricular activities in colleges include professional engineering societies - student chapters, engineering clubs/organizations, freshman orientation programs, sororities and fraternities, engineering academic honor societies, sports (recreation \& club), band/orchestra, and ROTC [3]. Since involvement in extracurricular activities is voluntary and usually based on the inherent interests of the students [4], it can serve as an avenue for the individual to develop student interests and talents, independent of the engineering curriculum [3]. Typically extracurricular activities satisfy the following criteria [3]: (1) not a requirement for graduation, (2) voluntary participation, (3) structured; participants meet regularly in a context specific to the activity, and (4) requires efforts; it must pose some measure of challenge to the individual engaged in the activity.

The motivations for getting involved in EPA P3 projects were to become more attractive to potential employers (e.g., resume builder), to learn hands-on experience on emerging technologies, and to fulfill an intrinsic interest in Environmental Sustainability. Extracurricular activities through EPA P3 projects collectively demonstrated leadership, commitment of research time (e.g., 10 hours per week), passion, time management, and improved interpersonal relationship with others in a team-building setting. Students' perceptions of the role of EPA P3 activities in the professional preparation of engineering students were clear. Students that participated in several National Student Design Competitions for Sustainability felt that these activities provided them with the opportunity to practice the eleven ABET Learning outcomes such as the skill of applying knowledge of mathematics, science and engineering, the ability to function on multidisciplinary teams, and ability to communicate effectively.

\section{Educational and students learning outcomes through EPA $P 3$ projects}

Table 1 shows the assessment of educational and students learning outcomes components through extracurricular P3 approach. During the Project periods, mentoring and student learning were assessed by identifying the following four strategic program goals: 1) Engage and educate the next generation of scientists, engineers, and the greater academic and external communities in understanding and using the P3 approach (i.e., how the research is beneficial to people, prosperity, and the planet), 2) Support the development of innovative technologies that will contribute to improved social, environmental, and economic well-being, especially in communities with the greatest needs, 3) Support the demonstration of P3-developed technologies to prove their effectiveness and value, and 4) Foster the development of enterprises that will disseminate technologies in the target communities and elsewhere. Assessment of environmental engineering education components through extracurricular EPA P3 projects was conducted for three projects over three years as each award (Phase I) has 1 year of project duration. This includes the recruit of potential undergraduates from classroom, research project idea formation, proposal development, peer-reviewed paper publications, conference presentations, other internal 
and external educational activities (STEM activities and mentoring NSF RET teachers). Through the processes, students had the opportunity to experience all the steps involved in a scientific endeavor, starting from conceiving an idea from their literature review and conducting experiments in the lab to finally building up a scientific proposal for materializing their vision. They also learned how to find potential collaborators in other disciplines (e.g., biology, chemistry, and biomedical engineering) on campus.

Table 1. Assessments through ABET outcomes

\begin{tabular}{|c|c|}
\hline ABET Leaning Outcome & EPA P3 progression \\
\hline $\begin{array}{l}\text { (a) Ability to apply knowledge of } \\
\text { mathematics, science, and } \\
\text { engineering }\end{array}$ & $\begin{array}{l}\text { - Execute the research activities } \\
\text { - Understanding fundamentals of other disciplines } \\
\text { (e.g., contact angle measurements, cyclic } \\
\text { voltammetry, lipid analysis for biofuel } \\
\text { potentials) }\end{array}$ \\
\hline $\begin{array}{l}\text { (b) Ability to design and conduct } \\
\text { experiments, as well as to analyze } \\
\text { and interpret data }\end{array}$ & $\begin{array}{l}\text { - Brainstorming of the ideas } \\
\text { - Construction of reactors } \\
\text { - Design experiments (required time, chemicals, } \\
\text { parameters to be considered, control issues) } \\
\text { - Evaluation of the experimental data } \\
\text { - Excel spreadsheet, other graphical tools for data } \\
\text { analysis (Prism, SigmaPlot, etc.) }\end{array}$ \\
\hline $\begin{array}{l}\text { (c) Ability to design a system, } \\
\text { component, or process to meet } \\
\text { desired needs within realistic } \\
\text { constraints such as economic, } \\
\text { environmental, social, political, } \\
\text { ethical, health and safety, } \\
\text { manufacturability, and } \\
\text { sustainability }\end{array}$ & $\begin{array}{l}\text { - The system and/or process design consideration } \\
\text { based on the P3 (Planet, Prosperity, and People) } \\
\text { (Fig. 1) } \\
\text { - Relation of challenge to the P3 } \\
\text { - Research activities that promote and incorporate } \\
\text { sustainability principles. }\end{array}$ \\
\hline $\begin{array}{l}\text { (d) Ability to function on } \\
\text { multidisciplinary teams }\end{array}$ & $\begin{array}{l}\text { - Most engineering programs have little or no } \\
\text { opportunities for students to work with students } \\
\text { from other departments [3]. } \\
\text { - Through three P3 awards, students from } 8 \\
\text { different disciplines were involved to make the } \\
\text { project successful (Fig. 2) }\end{array}$ \\
\hline $\begin{array}{l}\text { (e) Ability to identify, formulate, and } \\
\text { solve engineering problems }\end{array}$ & $\begin{array}{l}\text { - Literature review and summary } \\
\text { - Weekly meeting, discussion, and research } \\
\text { progress presentation } \\
\text { - Freedom to consider numerous options } \\
\text { - Multifaceted advices on campus (e.g., } \\
\text { discussion with faculty in other disciplines) } \\
\text { - Other resources on campus (e.g., Material } \\
\text { Characterization Facility) }\end{array}$ \\
\hline
\end{tabular}




\begin{tabular}{|c|c|}
\hline $\begin{array}{l}\text { (f) Understanding of professional and } \\
\text { ethical responsibility }\end{array}$ & $\begin{array}{l}\text { - Literature review on the topic (at least } 25 \\
\text { papers) } \\
\text { - Critical review on participant's document } \\
\text { - Literature review on Professionalism } \\
\text { - Understanding academic integrity and research } \\
\text { misconduct (data falsification) } \\
\text { - Checking plagiarism on each document (e.g., } \\
\text { iThenticate, Plagiarism detection software) } \\
\text { - Business attire and etiquette (e.g., presentation) } \\
\text { - Learning how to apply provisional patents }\end{array}$ \\
\hline (g) Ability to communicate effectively & $\begin{array}{l}\text { - National Expo participation and demonstration } \\
\text { to K-12 and other audiences } \\
\text { - Poster preparation } \\
\text { - Power point slides preparation } \\
\text { - Weekly meeting, discussion, and research } \\
\text { progress presentation } \\
\text { - } 1 \text { min elevator pitch considering diverse } \\
\text { - } \text { audiences } \\
\text { - Showcase of Undergraduate Research } \\
\text { - Finariences } \\
\text { - Phase II proposal preparation and submission } \\
\text { - Interview with various local media (e.g., } \\
\text { Spectrum News Channel 13, WFTV Channel 9, } \\
\text { UCF Today, and the University Network) } \\
\text { - Conference proceedings } \\
\text { - Peer-reviewed journal paper publications }\end{array}$ \\
\hline $\begin{array}{l}\text { (h) The broad education necessary to } \\
\text { understand the impact of } \\
\text { engineering solutions in a global, } \\
\text { economic, environmental, and } \\
\text { societal context }\end{array}$ & $\begin{array}{l}\text { Multidisciplinary collaboration (9 different } \\
\text { disciplines) } \\
\text { - Multifaceted approach to solve engineering } \\
\text { problems } \\
\text { - Better understanding of P3 (Planet, Prosperity, } \\
\text { and People) related to the research topics }\end{array}$ \\
\hline $\begin{array}{l}\text { (i) A recognition of the need for, and } \\
\text { an ability to engage in life-long } \\
\text { learning }\end{array}$ & $\begin{array}{l}\text { - All participants felt the important of real-life } \\
\text { experiences } \\
\text { - All participants felt great achievements when } \\
\text { their proposal was accepted and funded \& } \\
\text { received honorable mention: Sustainable energy } \\
\text { award at the National Expo, 4th USA Science \& } \\
\text { Engineering Festival, Washington DC, } 2016 \\
\text { - All participants agreed that lifelong learning is } \\
\text { important. } \\
\text { - Considering pursuing graduate (MS or Ph.D.) } \\
\text { study }\end{array}$ \\
\hline
\end{tabular}




\begin{tabular}{|c|c|}
\hline & $\begin{array}{l}\text { 0.5-year preparation and 1-year project } \\
\text { execution per each P3 project (37.5\% of } \\
\text { participants' 4-year university life) }\end{array}$ \\
\hline (j) Knowledge of contemporary issues & $\begin{array}{l}\text { - Literature reviews } \\
\text { - Searching up-to-date technology, environmental } \\
\text { regulations, research direction } \\
\text { - Finding niche area }\end{array}$ \\
\hline $\begin{array}{l}\text { (k) Ability to use the techniques, skills, } \\
\text { and modern engineering tools } \\
\text { necessary for engineering practice }\end{array}$ & $\begin{array}{l}\text { - Laboratory experiences (wet-lab, clean room, } \\
\text { etc.) } \\
\text { - Sophisticated equipment operations (e.g., SEM- } \\
\text { EDS, microsensors, zeta potential } \\
\text { measurements, and GC analysis) } \\
\text { - Hand-on skill } \\
\text { - Construction of home-made device (e.g., flow } \\
\text { cell) } \\
\text { - Learning software (e.g., a chemical equilibrium } \\
\text { modeling system, MINEQL+) } \\
\text { - Microsoft office word, power points, excel }\end{array}$ \\
\hline
\end{tabular}

Fig. 1. One representative example of Sustainable Primer (14 ${ }^{\text {th }}$ EPA P3 award Phase I) which describes how the project embodies the P3 approach and seeks sustainable solutions that protect the environment, strengthen our communities and create economic benefits: Expected outcomes and relationship of challenge to sustainability.

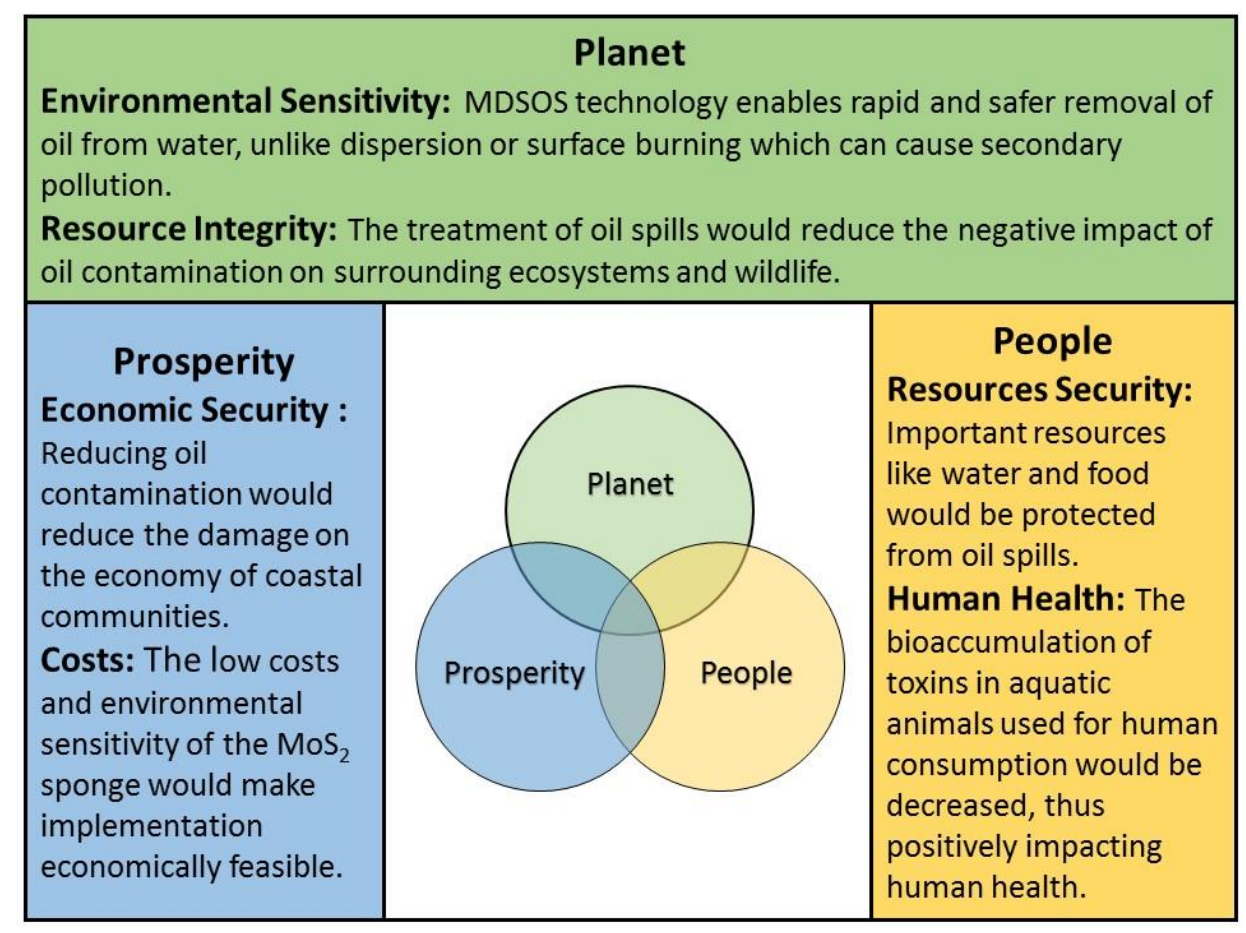

\section{Participants involved}


For each project, an interdisciplinary student team at UCF was made and collaborated to develop the designs for the project and the project was carried out by the interdisciplinary student team (usually 3-6 undergraduates and one graduate student) with environmental engineering, chemistry, biochemistry, biotechnology, environmental sciences, biomedical sciences, physics, and electrical engineering majors. Since 2015, a total of 16 students were involved in three Phase I and one Phase II projects. Table 2 shows the distribution of the participants with respect to gender, classification, GPA, and discipline.

Table 2. Distribution of participants

By gender

\begin{tabular}{|l|l|}
\hline Gender & $\%$ \\
\hline Male & 50 \\
\hline Female & 50 \\
\hline
\end{tabular}

By Classification
\begin{tabular}{|l|l|}
\hline Classification & $\%$ \\
\hline Sophomore & 6 \\
\hline Junior & 38 \\
\hline Senior & 56 \\
\hline
\end{tabular}

By GPA
\begin{tabular}{|l|l|}
\hline GPA & $\%$ \\
\hline$\geq 3.4$ & 81 \\
\hline $\begin{array}{l}\geq 3.0 \& \\
<3.4\end{array}$ & 13 \\
\hline$<3.0$ & 6 \\
\hline
\end{tabular}

By discipline

\begin{tabular}{|l|l|l|l|}
\hline Discipline & \% & Discipline & \% \\
\hline Aerospace Engineering & 6 & $\begin{array}{l}\text { Environmental } \\
\text { Engineering }\end{array}$ & 37 \\
\hline Biology & 13 & Environmental Studies & 6 \\
\hline Biomedical Science & 13 & Mechanical Engineering & 6 \\
\hline Biotechnology & 13 & Physics & 6 \\
\hline
\end{tabular}

\section{Student recruitments}

The diverse group of students was motivated by personal experiences, and they each brought unique skill sets that helped the team develop its invention. For example, the role of one undergraduate student from Biotechnology on the team was to bring a biotechnological perspective to the project, which focuses on the cellular and biomolecular process of what we are trying to achieve, and expand on those processes in application to commercial production. Most participants were recruited as research volunteers or from classroom which the PI taught during the semester. During the proposal development (2-3 months), participants had a regular meeting with the principal investigator (PI) to produce ideas and discuss their findings from literature reviews. They also conducted a brief preliminary test on the ideas which were discussed and finalized in the laboratory. For each project, a quality assurance and quality control (QA/QC) plan was created and their potential end users and partnerships were identified for their technology applications.

\section{Leadership improvement}

The engineering education community has begun to focus on leadership abilities of undergraduate students in engineering fields [5]. Higher education institutions have been criticized for their lack of success in instilling leadership abilities within recent engineering 
graduates via reports from ABET, the National Academy of Engineering, and the National Research Council [5]. The importance of leadership development among undergraduate engineering students has been recognized and leadership has been incorporated into these P3 extracurricular activities (e.g., student team leader). In addition, the leadership of P3 was expanded to another extracurricular activity of NSF I-Corps. Currently one of the student team leaders $\left(14^{\text {th }}\right.$ award with a topic of superhydrophobic sponges for oil-water separation) has been involved in the UCF's NSF I-Corp program to further develop the P3 solution, working with industrial mentors that will aid in overcoming obstacles that appear, and also obtaining an awareness regarding the market for developed products and the best course of action to implement our products. In 2019, the P3 student team applied for a NSF I-Corp program (nominated by UCF's I-Corp program manager) for further development of the technology. The broad nature of this $\mathrm{P} 3$ project will establish a strong collaborative network that will persist long after the grant period for participating undergraduate students.

\section{Interview with local media}

For $14^{\text {th }}$ EPA P3 Phase I project (A Novel 2D MoS 2 Sponge Oil-Water Separator), participants had experience of interviews with local media (e.g., The University Network, Central Florida Lifestyle Magazine, Spectrum News Channel 13, and WFTV Channel 9). The followings are some examples of student perceptions on the $\mathrm{P} 3$ projects.

- "The team and the project itself truly reflect the spirit of the University, with people from many different backgrounds and majors coming together to create a novel interdisciplinary answer to a major problem. I still can't believe how far the team has come since the Phase I proposal, and I can't wait to see where we can go in the future."

- "It was my first ever project in this research group and I loved it, I wanted to support innovative answers to real-world problems."

- "Not only could we meet other competing teams and people from EPA, NASA, Lockheed, and other big names, we were able to reach out to and inspire K-12 students who were interested in the STEAM fields,"

- "While biotechnology is my specialty, one of the best aspects of being part of this project is having other students who come from a variety of fields work together to create something truly interdisciplinary."

- "Ever since I was little, I wanted to make a difference in the environmental sustainable aspects of engineering. I had extra motivation in the project because of the Deepwater Horizon oil spill of 2010, which occurred near Mexico, where my family is from."

- "It is an incredible feeling knowing that people see a lot of value in our research and know that this is something that can help people and the environment. It is really rewarding."

- "We want to keep our water bodies clean. We want to make sure you know people benefit from our research, and being so close and knowing that yes, we can do this - it is an amazing feeling."

Up to date, total 6 research presentations with undergraduates were conducted at the national conferences including ACS meeting and Membrane Technology Conference. Internally, total 12 research presentations at Showcase of Undergraduate Research Excellence (SURE) were 
conducted at the university. In addition, participating students received many internal and external awards including an American Membrane Technology Association (AMTA) Undergraduate Research Fellowship and an America Chemical Society (ACS) Undergraduate Student Award in Environmental Chemistry. The project has given the interdisciplinary team of students an excellent experience in how to work together to solve problems putting to use their areas of expertise and learning from each other.

Overall, the P3 program successfully promoted undergraduate research and educations by improving intellectual merit and disseminating findings to societies for broader impact by connecting the research with the real-world solutions for environmental problems (e.g., bioenergy production from algae and a lead detecting sensor for drinking water).

\section{References}

1. American Society of Civil Engineers. Body of Knowledge Committee, Civil engineering body of knowledge for the 21st century: Preparing the civil engineer for the future. 2008. ASCE.

2. Commission, E.A., Criteria for accrediting engineering programs: Effective for reviews during the 2016-2017 accreditation cycle. Baltimore, MD: ABET, 2015.

3. Dalrymple, O. and D. Evangelou. The role of extracurricular activities in the education of engineers. in 9th International Conference on Engineering Education. 2006. San Juan, Puerto Rico.

4. Mahoney, J.L., B.D. Cairns, and T.W. Farmer, Promoting interpersonal competence and educational success through extracurricular activity participation. Journal of educational psychology, 2003. 95(2): p. 409.

5. $\quad$ Cox, M.F., O. Cekic, and S.G. Adams, Developing Leadership Skills of Undergraduate Engineering Students: Perspectives from engineering faculty. Journal of STEM Education: Innovations \& Research, 2010. 11(3-4): p. 22-33. 